Acta Technologica Agriculturae 3

Nitra, Slovaca Universitas Agriculturae Nitriae, 2016, pp. 57-62

\title{
PROSPECTS OF COIR FIBRE AS REINFORCEMENT IN TERMITE MOUND CLAY BRICKS
}

\author{
Banjo A. AKINYEMI*1, Temidayo. E. OMONIYI², Micheal O. ADEYEMO' \\ ${ }^{1}$ Landmark University Omuaran, Nigeria \\ University of Ibadan, Nigeria
}

\begin{abstract}
The study is to develop an appropriate environmental friendly building material that would be sourced, obtained locally and used for construction of structures at a low cost by using termite mound soil, reinforced with $0 \%, 1 \%, 2 \%, 3 \%$. and $4 \%$ coir fibres. Physical and mechanical tests were conducted on the different composition samples after curing. The particle size distribution showed that clay had the largest percentage with a moisture content of 3.53\%, specific gravity of 2.0 , liquid limit of $30.5 \%$ and plastic limit value of 25.4. The compressive strength test showed a decrease with increase in fibre content from $1 \%$ upward, modulus of rupture test showed that increase in fibre content leads to a corresponding increase in rupture while the modulus of elasticity test showed that from $3 \%$ to $4 \%$ fibre content, a decrease in the elasticity occurred. It can be concluded that low fibre inclusion into compressed termite mound brick is feasible if fibre content do not exceed $2 \%$ and thus can be used for both load and non-loading bearing structures.
\end{abstract}

Keywords: termite mound; bricks; clay; coir fibre; physical and mechanical properties

Earth has been used for building for thousands of years throughout the world spanning a diverse range of climates and cultures. Earth itself is a multi-component system usually consisting of stones, sand, silt, clay, water and, near the ground surface, organic humus. Structural stability of earth buildings is maintained by the structural integrity of the sand and stone framework, by the pore filling capacity of the silt and, most importantly, by the binding qualities of the clay, which are in turn influenced by the moisture content of the soil (Practical Action, 2008; Galán-Marín et al., 2010). The clay content in any sample of termite mound soil has higher percentage composition than other types of soil in its surroundings (Sarcinelli et al., 2009; Dhembare, 2013). The predominant termite mound building species found in Nigeria are the Macrotermes bellicosus and Trinevitermes germinates, the former dominant species can be found primarily in South Westerns states of Kwara, Osun, Ekiti and Oyo (Olusola, 2006). The possibilities of usage of termite mound soil as low cost building material have been studied in order to determine the strength, durability, and engineering properties (Mijinyawa and Omobowale, 2013) with a view to evaluate whether it could be used to replace more costly building materials particularly for low income earning countries such as Nigeria (Alabadan, 2012). When used as reinforcement element in building materials, natural organic fibres have been observed as improving certain engineering properties of the matrix when dispersed in form of fibres during the mixing process (Omoniyi and Akinyemi, 2012; Omoniyi et al., 2013). Termite mound bricks can be produced either by using press or by means of the uncompressed way by simply filling up the mould with the already prepared mixture, and afterwards, allowing it to dry slowly in a shade for further improvement of its strength and to reduce cracking. They can also be fired in traditional kilns in order to increase its strength when it is to be used for structures bearing load (Mijinyawa et al., 2007; Heavy and Park, 2015).

The objective of this research is to develop an appropriate building material which would be sourced and obtained locally and used for construction of houses and walls in rural areas at a low cost and also to observe the suitability of using coir fibre as reinforcement element in the termite mound bricks.

\section{Material and methods}

\section{Termite mound soil}

The termite mound soil (TMS) used for the research was sourced from a cluster of termite mounds located in Landmark University Omu Aran, Kwara State of Nigeria. At first, these mounds were broken down into large clumps and subsequently they were manually broken into smaller particles and packed into polythene bags for analysis at the Geotechnical and Structure Laboratories. Soil analysis test was conducted (ASTM D4318 and ISO 3310-1:2000) on the TMS in order to perform the sieve analysis, moisture content determination test, compaction test, specific gravity test, liquid limit test, plastic limit test and plasticity index (Obradovic et al., 2009; KeShun, 2009). 


\section{Coir fibres}

Large amount of coir fibres was acquired from the Omuaran market and then the husks were removed manually (Figure 1). To remove dust and small particles, they were sieved using sieve of $2.00 \mathrm{~mm}$ diameter and then the fibres were treated using hot water treatment method which involved soaking the fibres with hot water (Saxena et al., 2011) at a boiling

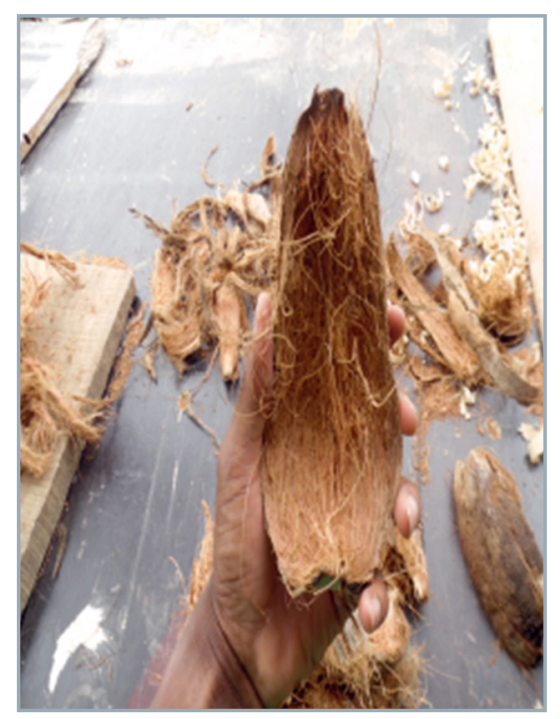

Figure 1 Coir fibre

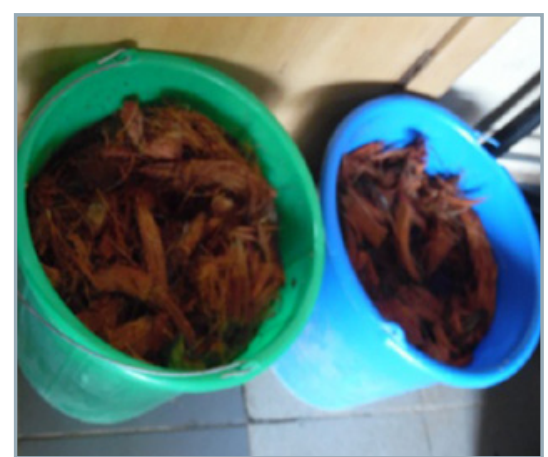

Figure 2 Hot water treatment

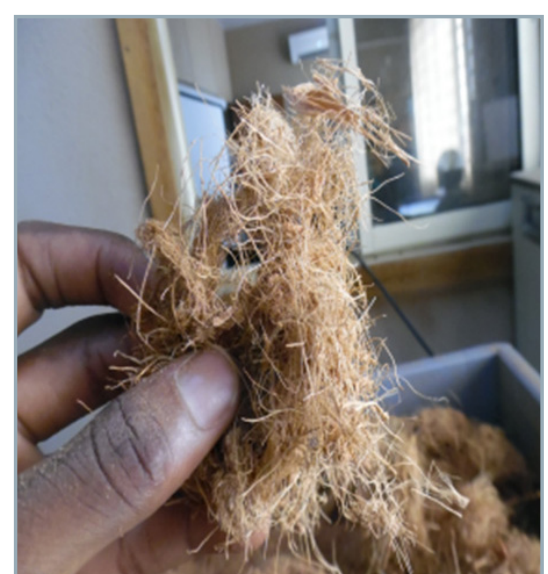

Figure $3 \quad$ Coir fibre after cutting temperature of $80{ }^{\circ} \mathrm{C}$ inside two buckets for 90 minutes (Figure 2) while a mercury-thermometer was used to constantly check the temperature. This was done in order to remove lignin and cellulose from the fibres, thereafter it was sun dried for 6 hours. Finally, they were cut into smaller length of $6 \mathrm{~mm}$ fibres (Figure 3) using hammer mill machine while part of them were cut using scissors.

\section{Cement}

Portland cement type 1 was procured from the concrete laboratory and it conforms to ASTM C 150 Standard Specification for Portland Cement.

\section{Crushed sand}

Used crushed sand was obtained from a construction site located within Landmark University, Nigeria and was graded for ensuring that it is of the appropriate density and grain size distribution.

\section{Water}

Potable water from a sunk borehole located close to the Laboratory was used for all sample mixture used in the TMS brick production.

\section{Experimental mixture}

With reference to research conducted by Omoniyi and Akinyemi (2012) and Yalley and Kwan (2009), it was suggested that small amount of fibre should be used because natural fibre is used as reinforcement in concrete medium in order to reduce the cyclic wetting and drying effect in the environment which would reduce durability of the material and lead to structural failure; therefore the content of $0-4 \%$ fibre reinforcement was designed as shown in Table 1. Three blocks were produced in order to obtain an average result for each mix proportion; altogether fifteen

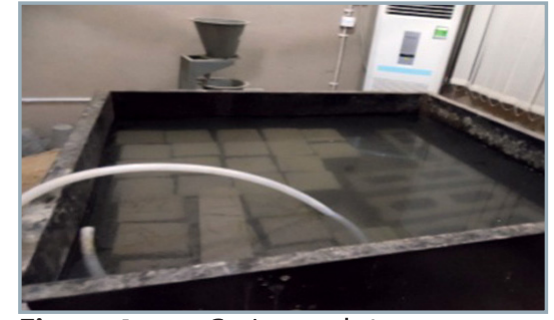

Figure 4a Curing tank 1

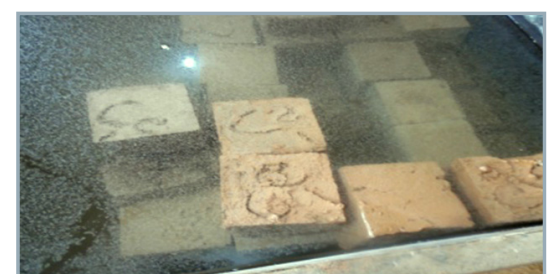

Figure 4b Curing tank 2

sample bricks were produced for the physical and mechanical tests. Before the mixing, appropriate volumes for termite mound soils, cement, and sharp sand were determined using a small custard bucket labelled inside with a paper tape lined up with the measurement of a ruler inscribed with a marker while the appropriate amount of fibre and water was determined by means of weighing balance. The usual issue, occurring when mixing natural fibres with other composites, is balling of the fibres. This was eliminated by mixing dry sand and cement separately, the dry coir fibres were wetted by dipping in the mixing water and spread over the sand-cement mix. The mixture of wet fibres and the sand-cement was then properly mixed together and the remaining mixing water added gradually and mixed until the fibres were evenly distributed in the mixture. The mixture was poured into a mould and compacted manually using hydraulic jack. All specimens were demoulded after 24 hours of casting and cured in water at room temperature using the curing tank for 14 days (Figure $4(A)$ and (B)).

Table 1 Mixture proportioning

\begin{tabular}{|c|c|c|c|c|c|}
\hline $\begin{array}{c}\text { Termite } \\
\text { mound (\%) }\end{array}$ & $\begin{array}{c}\text { Sharp sand } \\
\text { (\%) }\end{array}$ & $\begin{array}{c}\text { Cement } \\
(\%)\end{array}$ & $\begin{array}{c}\text { Coir fibre } \\
(\%)\end{array}$ & $\begin{array}{c}\text { Water } \\
\text { content (g) }\end{array}$ & $\begin{array}{c}\text { Replicate } \\
\text { (QTY) }\end{array}$ \\
\hline \hline 70 & 20 & 10 & 0 & 10 & 3 \\
\hline 70 & 20 & 9 & 1 & 10 & 3 \\
\hline 70 & 20 & 8 & 2 & 10 & 3 \\
\hline 70 & 20 & 7 & 3 & 10 & 3 \\
\hline 70 & 20 & 6 & 4 & 10 & 3 \\
\hline
\end{tabular}




\section{Physical and mechanical tests} Water absorption test

The water absorption test was performed in accordance with ASTM D570 standards. After 14 days of curing, the specimens (Figure 5) were removed from the tank, excess moisture was drained using cloth and the specimens were oven dried at temperature $50{ }^{\circ} \mathrm{C}$ for 24 hours in order to obtain the dry weight of it. Then it was immersed in water (Figure 6) inside two buckets for 24 hours in order to acquire the weight of the wet specimen. After 24 hours, the specimens were taken out of water; excess moisture was removed by cleaning them with dry cloth. Finally, the wet weight was measured using the weighing balance.

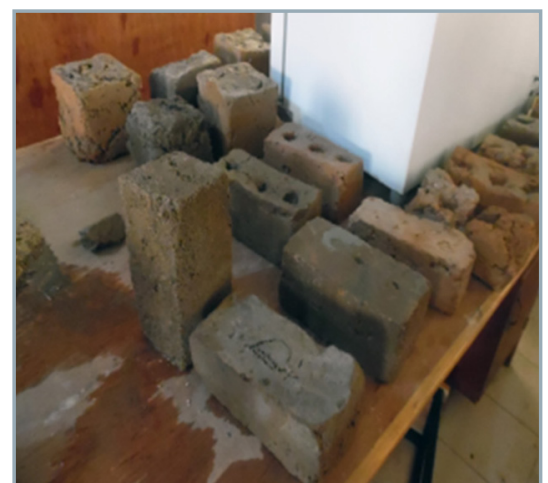

Figure 5 Termite mound brick specimens

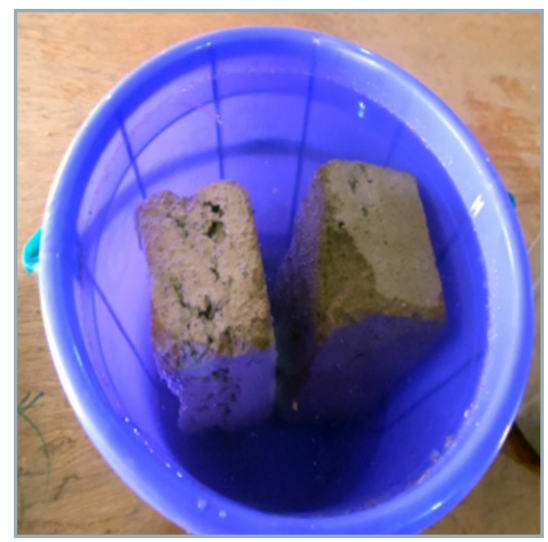

Figure $6 \quad$ Immersion in water

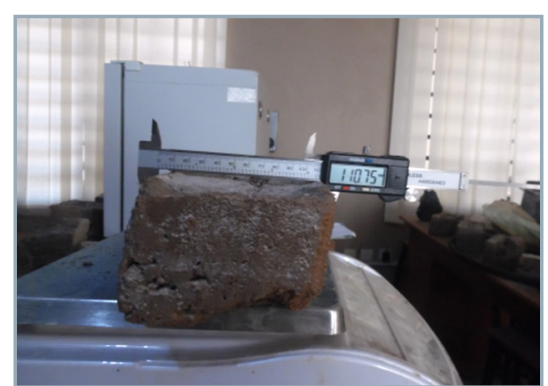

Figure 7 Thickness swelling
The water absorption value of the specimen was calculated using the equation below:

$$
W A=\frac{M_{2}}{M_{1}}-M_{1} \times 100
$$

where:

$M_{1}$ - weight of dry specimen

$M_{2}$ - weight of wet specimen

\section{Thickness swelling test}

The swelled specimens were of the thickness $230 \times 130 \mathrm{~mm} \times 110 \mathrm{~mm}$. The samples were soaked in distilled water for 24 hours. The immersed samples were taken out and wiped with dry cloth in order to remove water from the surface. The thickness was measured using a digital vernier calliper (Figure 7) at room temperature and average results were recorded. The thickness swellings of the samples were calculated according to ASTM D1037 standards.

\section{Compressive strength test}

The universal crushing machine was used on the specimens each of $150 \times$ $150 \times 150 \mathrm{~mm}$ and with volume of $33,750 \mathrm{~cm}^{3}$. The measured specimens

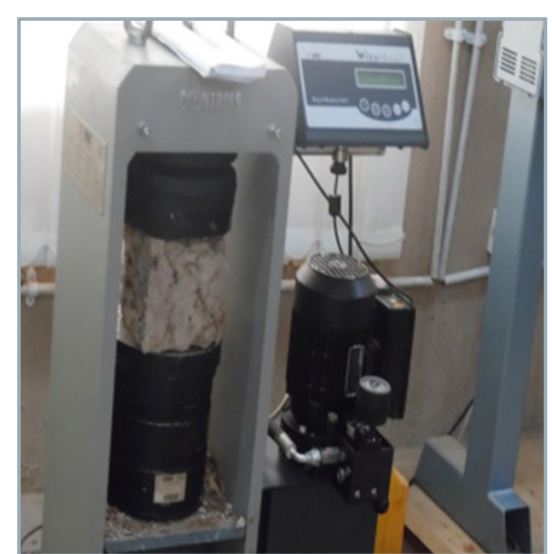

Figure 8

Compressive strength test

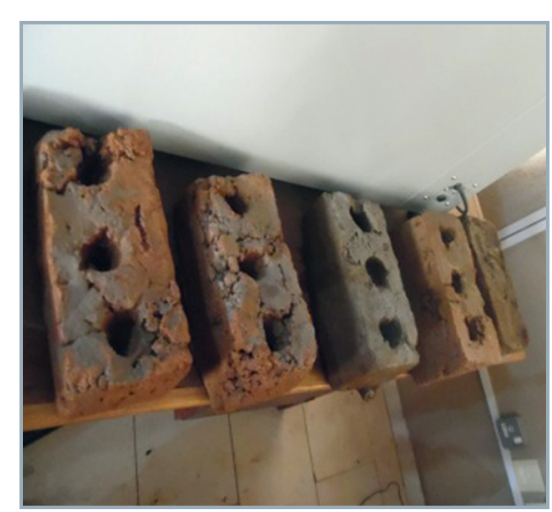

Figure 9
Modulus of brick specimens were placed on the flat loading base with the cast surface placed perpendicular to the base surface as shown in Figure 8 . The loading plate was lowered to touch the specimen and loading rate maintained at $4 \mathrm{kN} / \mathrm{m}^{2} \cdot \mathrm{min}$ in accordance with the requirements of B.S 1881 standards until failure occurred. The equation below was used to calculate the compressive strength of each specimen:

$$
C_{s}=\frac{\text { compressive load }}{\text { crossectional area of the specimen }}
$$

\section{Modulus of rupture test}

In accordance with the requirements of ASTM C67 standards, a mould of $230 \times 130 \times 110 \mathrm{~mm}$ and with volume of $3289 \mathrm{~cm}^{2}$ was used for brick casting (Figure 9); the bricks were demoulded after 24 hours and cured for 14 days after which the test was carried out using the same compressive strength test machine that was used previously until cracks occurred (Figure 10 and 11).

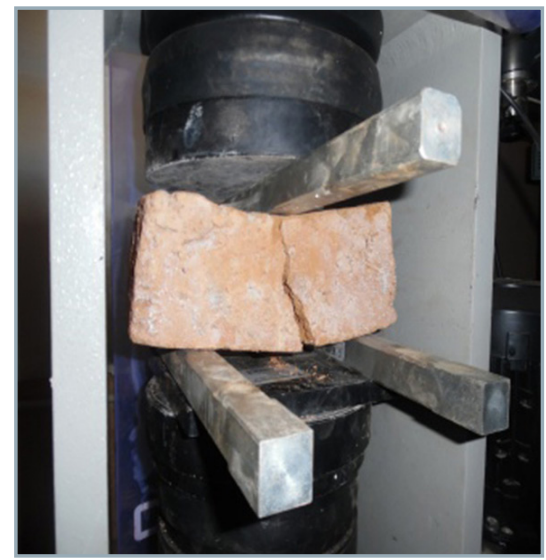

Figure 10 M.O.R. test

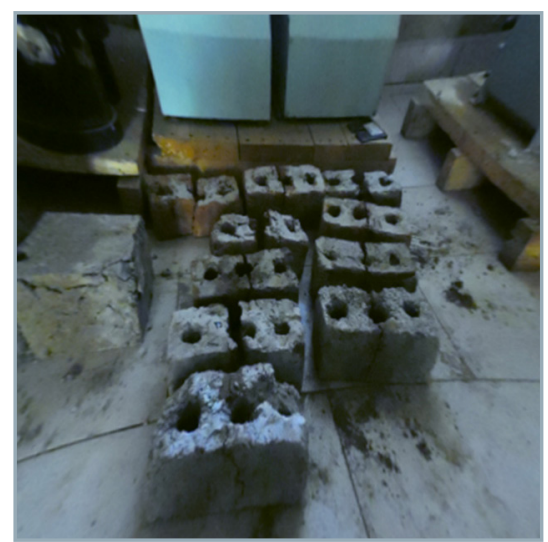

Figure 11 Crackeded bricks during M.O.R. test 
Values of the modulus of rupture (M.O.R.) of the bricks were calculated using the equation below:

$$
\mathrm{MOR}=\frac{3 P L}{2 b d^{2}}
$$

where:

$$
\begin{aligned}
P \quad- & \text { breaking load } \\
L \quad \text { - distance between bearing } & \\
& \text { rods on which samples were } \\
& \text { supported } \\
b \quad- & \text { breadth/width } \\
d \quad- & \text { depth/height }
\end{aligned}
$$

\section{Modulus of elasticity test}

The modulus of elasticity test was performed in accordance with EN 1992 standards. Using the compressive strength value obtained previously, the equation below was used to calculate the modulus of elasticity of the specimens.

$$
M O E=50 F c k
$$

where:

$$
\begin{gathered}
\text { Fck - characteristic compressive } \\
\text { strength }
\end{gathered}
$$

\section{Tensile strength test}

The tensile strength test was performed in accordance with ASTM C1006 standards. Using the compressive strength load $(F)$ applied on the bricks by the compressive machine, which was transferred back into the entire brick through the bearing rods and it generated a tensile stress over the height $(h)$ of the TMS brick, the distance between the split was measured $(I)$. The obtained values were used to calculate the splitting tensile strength $\left(f_{t s}\right)$ using Equation 5 (Haach et al., 2013).

$$
f_{t s}=\frac{2 F}{\pi h l}
$$

\section{Results}

\section{Physical and mechanical test results}

\section{Water absorption}

Water absorption (W.A.) was highest at $4 \%$ fibre content while the least W.A. value was observed at $0 \%$ fibre inclusion as seen in Figure 12. A low value of W.A. indicates that increase in fibre content leads to increase in the amount of water that will be absorbed by the bricks. The high W.A. results in

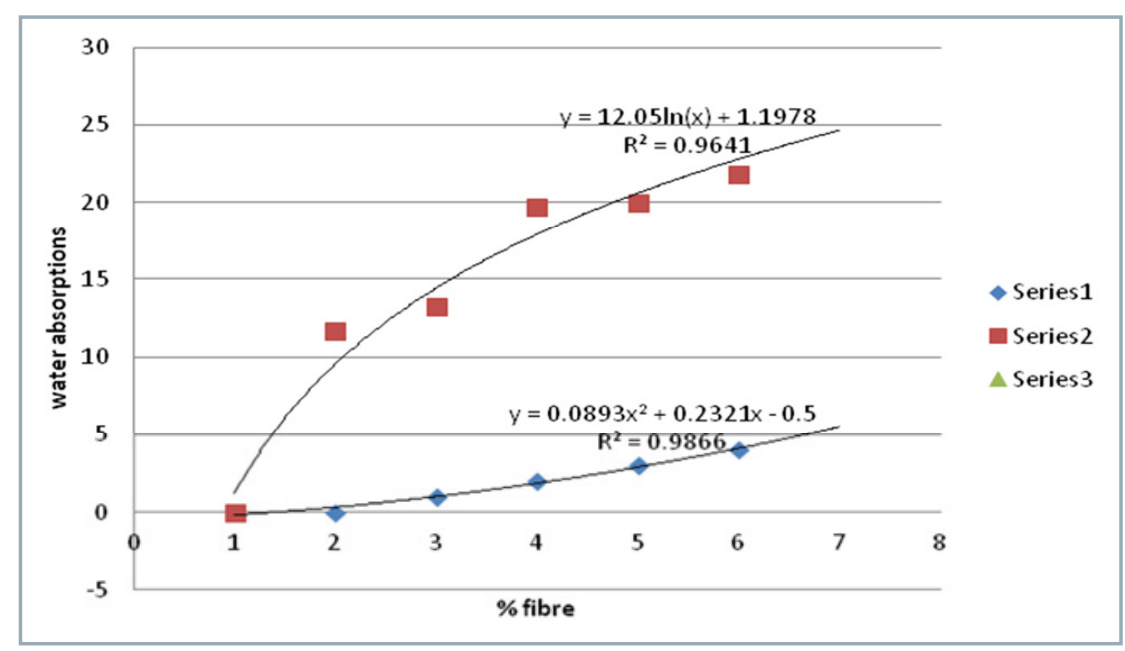

Figure 12 Water absorption graph

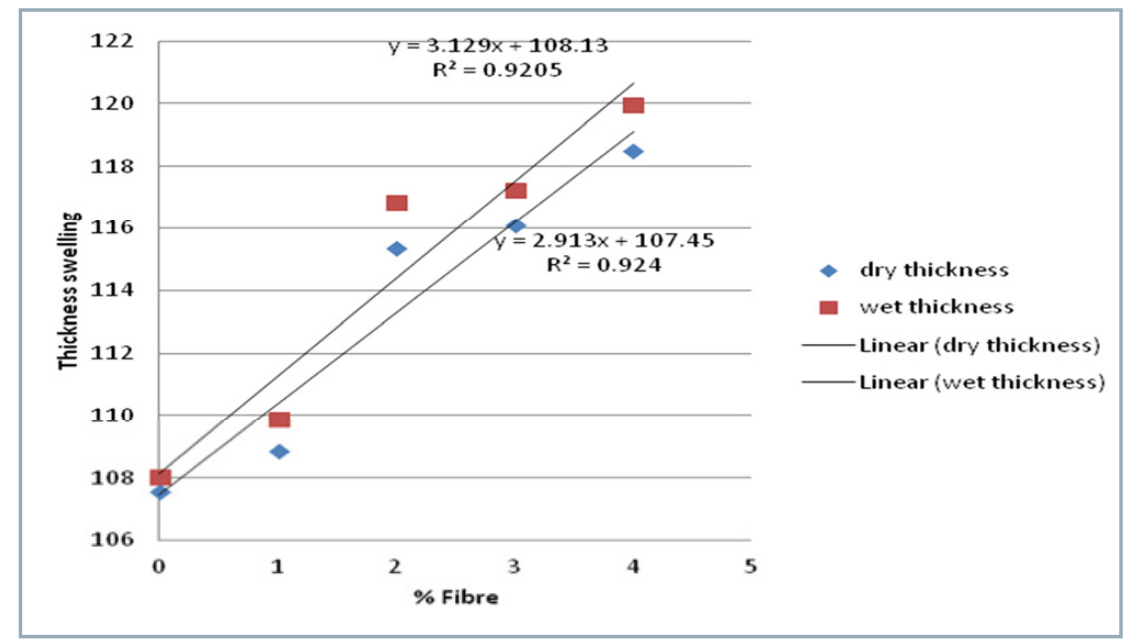

Figure 13 Graph showing thickness swelling

vulnerability to changes that will lead to cracking of bricks and structural damage in rural buildings. It can also lead to cracking in case of freezing, thawing of water inside the pores. Little absorption of water is also not desired because rain water, rather than getting partially absorbed by the brick, would tend to run off very quickly towards the joints and it may find its way into the building, as well as to cause reduction in durability of the mortar joints. The inclusion of cement to the bricks also enhanced their ability to stay in water without disintegrating immediately, clearly suggesting the necessity of baking if the bricks are meant for exterior use without protection (Chee-Ming, 2011).

\section{Thickness swelling}

The results showed that thickness swelling of the bricks after immersion in water for 2 and 24 hours without any chemical treatment was of the highest value at $4 \%$ fibre content and the least at $0 \%$ fibre content, signifying that the less the fibre content, the lower the thickness swelling (as shown in Figure 13). Therefore, thickness swelling increases with increase in fibre content of the composite brick. Also, the higher the cement content of the composite, the lower the thickness swelling which means more cement mixing on the fibres may have restrained the bricks from swelling. Considering the weather conditions of Nigeria, it is thus advisable to avoid higher fibre inclusion in TMC bricks so that during rainy season and other harsh climate occurrences like flooding, rural buildings will be safe in terms of dimensional stability.

\section{Compressive strength}

The compressive strength decreases with increase in fibre content (Figure 
14). The highest compressive strength of $0.62 \mathrm{~N} / \mathrm{mm}^{2}$ was measured in the TMC brick composition of $70 \%$ termite mound soil, $20 \%$ sharp sand, 10\% cement and $0 \%$ fibre which is close to the one obtained for lime stabilised clay bricks by Harper (2011). The lowest compressive strength was measured in the following composition: $70 \%$ termite mound soils, $20 \%$ sharp sand, $6 \%$ cement and 4\% fibre. The reduction in compressive strength

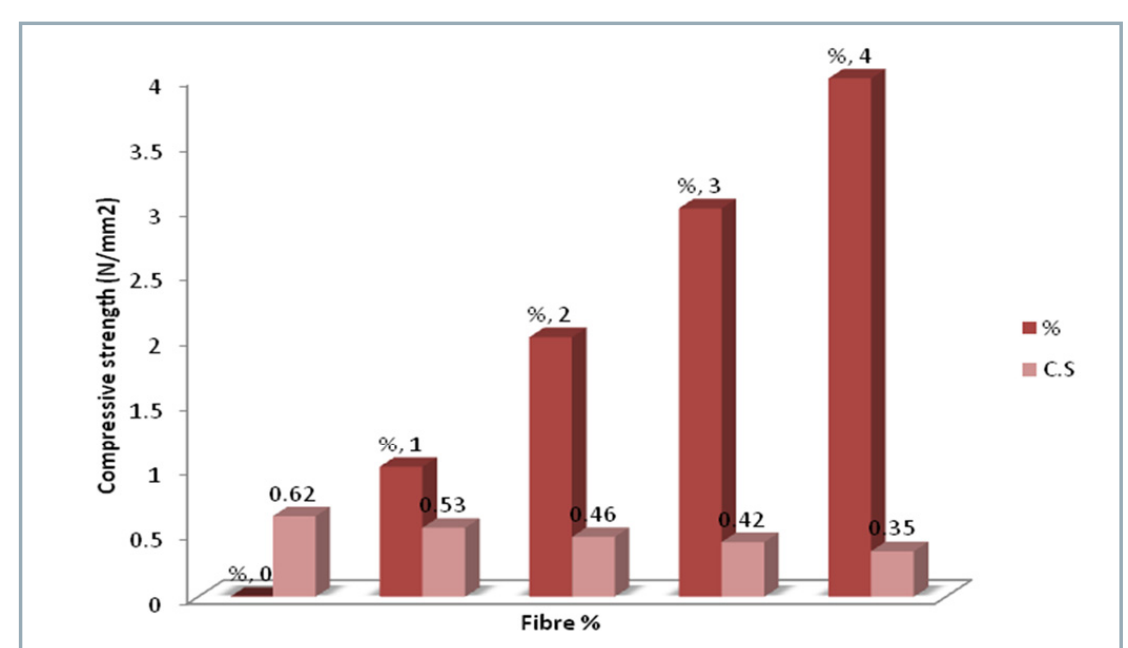

Figure 14 Compressive strength

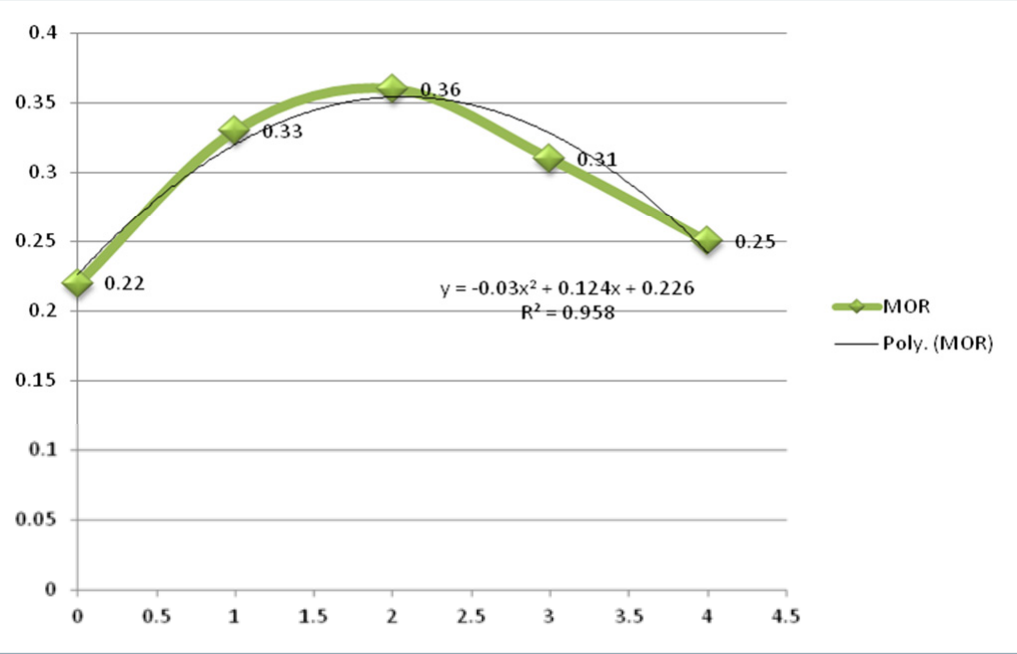

Figure 15 Modulus of rupture of fibre reinforced TMC bricks

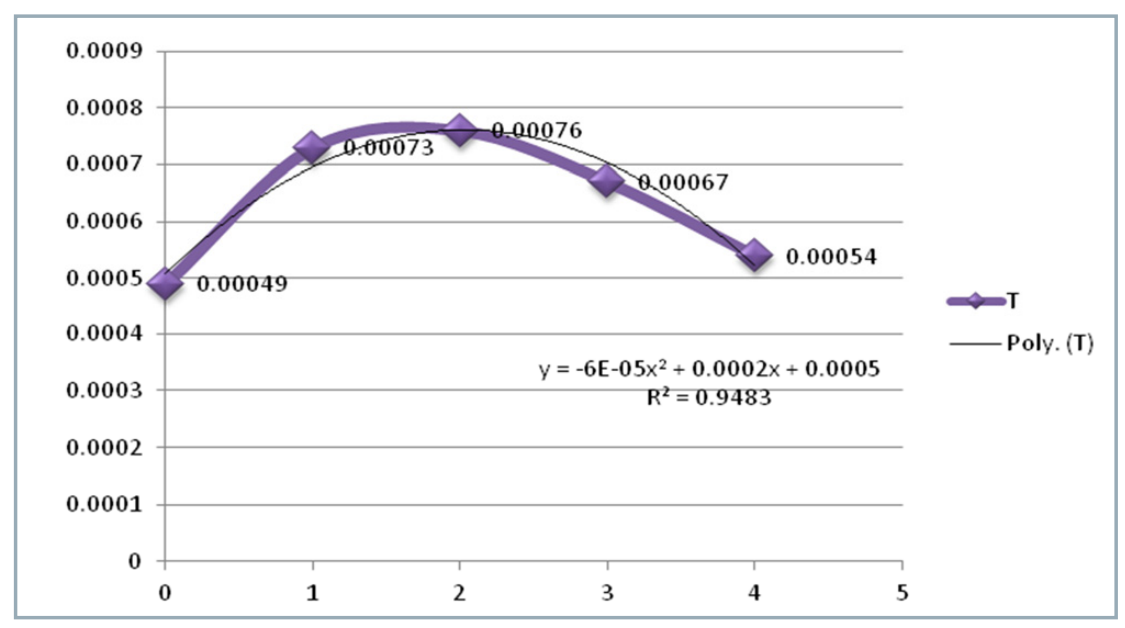

Figure $16 \quad$ M.O.E. graph due to increase in fibre content can be attributed to the fact that the elastic modulus of coir fibre is lower than that of the cement matrix. Since the compressive strength is highest at $0 \%$ fibre content followed by $1 \%$ fibre content, it is recommended that TMC bricks to be used for rural buildings should not exceed the range of 0 to $1 \%$ fibre inclusion so that the building will be able to withstand a moderate load.

\section{Modulus of rupture}

There is an observed increase in fibres from $0 \%$ fibre leads to an increment in rupture until it got to the peak at $2 \%$ fibre and declined from 3-4\% fibre (Figure 15). It was observed that an increase in fibre content from $3 \%$ upward led to an increase in rupture of bricks and this must be avoided for rural buildings and thus it is advisable to use fibre content between 0-1\% in fibre reinforced TMC bricks for their production. If $0-1 \%$ fibre inclusion is preserved, it will result in less cracking of fibre reinforced TMC bricks which can be caused by differential settlement, excessive tensile-nature loading and cyclic wetting and drying which is a major problem in any typical environment in Nigeria (Obada, 2005).

\section{Modulus of elasticity}

From 0-2\% fibre content (Figure 16), the elastic nature of the specimen decreases and from 3-4\% fibre content, there was an increase in elasticity, it is therefore observed that increase in fibre leads to decrease in the elastic nature of the bricks and hence tendency of deforming excessively. The flexibility of the bricks for rural buildings is at stake if there is an increment in the fibre content beyond the safe limit of $2 \%$. It is therefore recommended that fibre content ranging between $0-2 \%$ can be used in bricks, any higher inclusion may lead to failure due to deformation.

\section{Tensile strength}

The tensile strength was of the highest value at $2 \%$ fibre content and the lowest value was measured at $4 \%$ fibre content (Figure 17). This is an achievement of considerable importance because the result shows less cracking at $2 \%$ fibre content. After cracking and the maximum load have been attained, thereafter a decline in the tensile strength value was 


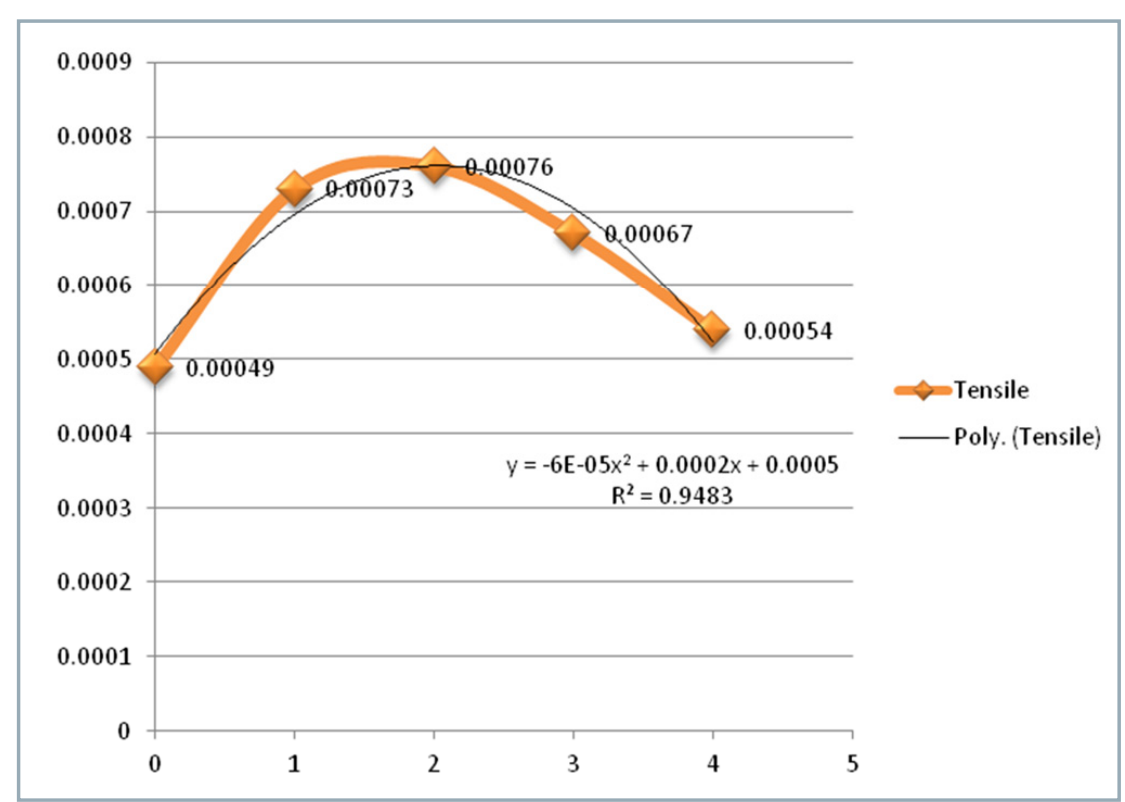

Figure 17 Tensile strength graph

observed from $3 \%$ to $4 \%$ fibre content due to localization of deformation at a single crack. Tensile strength depends mostly on the strength of mineral grains and of the matrix that binds them and cement was used as the binder in this case. Since the strength depends heavily on the weaker zones, the control sample having no fibre content provides a moderate tensile strength (Fernandes et al., 2009).

\section{Conclusion}

This study outlined the physical and mechanical characteristics of termite mound bricks reinforced with coir fibre; and based on the test results obtained, it was observed that the inclusion of coir fibre into termite mound bricks has a potential for use as a low cost building material in most rural areas in developing countries because of the availability of the constituent materials in the environment. The value from $1-2 \%$ coir fibre content as reinforcing element was found to be adequate and appropriate without putting the structure at risk.

\section{References}

ALABADAN, B. - MUSA, J. J. - ENEMAKU, L. E. 2012. Studies on Lime Treated Termite Mound Soil as a Low Cost and Energy Efficient Alternative Building Material. In Nig. J. Soil \& Env. Res, vol. 10, pp. 96-100. ASTM C1006-07. Standard Test Method for Splitting Tensile Strength of Masonry Units. 2007.
ASTM D570 - 98(2010) e1. Standard Test Method for Water Absorption of Plastics. ASTM D1037 - 12. Standard Test Methods for Evaluating Properties of Wood-Base Fiber and Particle Panel Materials.

ASTM D4318 - 10: 2014. Standard Test Methods for Liquid Limit, Plastic Limit, and Plasticity Index of Soils.

BS 1881-120:1983. Testing concrete. Method for determination of the compressive strength of concrete cores.

CHEE-MING, CH. 2011. Effect of natural fibres inclusion in clay bricks: physico-mechanical properties. In International Journal of Civil and Environmental Engineering, vol. 2011, 3, pp.1.

DHEMBARE, A. J. 2013. Physico-chemical properties of termite mound soil. In Archives of Applied Science Research, vol. 5, 2013, no. 6, pp. 123-126. concrete structures - Part 1-1: General rules and rules for buildings.

FERNANDES, F. M. - LOURENÇO, P. B. CASTRO, F. 2009. Ancient Clay Bricks: Manufacture and Properties. Published by Springer Science.

GALÁN-MARÍN C - RIVERA-GÓMEZ C. PETRIC J. 2010. Clay-based composite stabilized with natural polymer and fibre. In Construction and Building Materials, vol. 24, pp. 1462-1468.

HAACH, V. G. - VASCONCELOS, G. LOURENÇO, P.B. 2013. Development Of A New Test For Determination of Tensile Strength of Concrete Blocks. In 12th Canadian Masonry Symposium Vancouver, British Columbia.

HARPER, D. 2011. Alternative methods of stabilization for unfired mud bricks. In Engineers without Borders. Retrieved from: http://www.ewb-uk.org/filestore/20110514Mud\%20brick\%20construction.pdf.
EN 1992-1-1 2004. Eurocode 2: Design of
HEAVY, G. N. - PARK, E. 2015. Physical properties of unfired and compressed same clay brick composites reinforced with natural fibre from Tanzania. In Int. J. Inn. Res. Adv. Eng, vol. 2, 2015, pp. 4.

ISO 3310-1:2000. Test sieves - Technical requirements and testing - Part 1: Test sieves of metal wire cloth.

KAYALI, O. 2005. High performance bricks from fly ash. In World of Coal Ash (WOCA), Lexington, USA.

KESHUN, L. 2009. Some factors affecting sieving performance and efficiency. In Powder Technology, vol. 193, 2009, pp. 208-213.

MIJINYAWA, Y. - OMOBOWALE, M. O. 2013. Determination of some physical and mechanical properties of termite mound clay relevant to silo construction. In International Journal of Materials Engineering, vol. 3, 2013, no. 5, pp. 103-107. MIJINYAWA, Y - LUCAS, E. B. - ADEGUNLOYE, F. O. 2007. Termite mound clay as material for grain silo construction. In Agricultural Engineering International: the CIGR Ejournal. Manuscript BC 07 002, vol. 9, 2007. OBRADOVIC, V. - BRNCIC, M. - JEŽEK, D. 2009. Influence of the sieving amplitude on the particle size distribution of corn flour for direct expanded extrudates manufacturing. In Agriculturae Conspectus Scientificus, vol. 74, 2009, no. 3, pp. 249-252.

OLUSOLA, K. O. - OLANIPEKUN, E. A. ATA, O. - OLATEJU, O. T. 2006. Studies on termite hill and lime as partial replacement for cement in plastering. In Building and Environment, vol. 41, 2006, pp. 302-306.

OMONIYI, T. E - AKINYEMI, B. A. - OLUSOJI, A. O. 2013. Development of bamboo - rice husk ash and cement mixture for livestock house roofing sheets. In American J. Sci. and Ind. Res, vol. 4, 2013, no. 2, pp. 201-209. OMONIYI, T. E. - AKINYEMI, B. A. 2012. Durability based suitability of bagassecement composite for roofing sheets. In Journal of Civil Engineering and Construction Technology, vol. 3, 2012, no. 11, pp. 280-290. PRACTICAL ACTION. 2008. Technical Brief on Additives to clay. The Schumacher Centre for Technology \& Development.

SARCINELLI, T. S. et al. 2009. Chemical, physical and micromorphological properties of termite mounds and adjacent soils along a toposequence. In Zona da Mata, Minas Gerais State, Brazil. Catena 76, 2009, pp. 107-113.

SAXENA, M. - ASOKAN, P. - ANUSHA, S. - RUHI, H. - SONAL, W. 2011. Composite Materials from Natural Resources: Recent Trends and Future Potentials, Advances in Composite Materials Analysis of Natural and Man-Made Materials. In Tech Publication, 2011.

YALLEY, P. P. - KWAN, A. S. K. 2009. Use of coconut fibre as an enhancement of concrete. In Journal of Engineering and Technology, vol. 3, 2009, pp. 54-73. 